\title{
Jathilan Horse Dance: Spirit Possession Beliefs and Practices in The Present-Day Java
}

\section{Eva Rapoport 1}

\begin{abstract}
Jathilan is one of the names for traditional Javanese trance dance which takes its roots in the most archaic levels of local culture but remains very popular nowadays. It is also described as a horse dance for the horse effigies made of woven bamboo are the hallmark props used by the performers. Horse dance is a part of the folk culture, still untouched by institutionalization or commodification; it can be performed for both ritual and entertainment purposes. Trance is its main attraction, though through the lens of local beliefs it is interpreted in terms of spirit possession thus it is understood that spirits can enter performers' bodies and fulfill their needs while being manifest in material world, but also allow the dancers to perform various feats demonstrating invulnerability to physical harm (like eating glass, walking over hot coals, being whipped or even run over by a motorcycle).

The purpose of this paper is to provide a thorough description of how trance in jathilan is performed and understood, based on existing literature, practitioners' first-hand accounts and numerous performances observed and documented; but also to consider it in the wider context of Javanese beliefs and practices involving spirits, possession, and exorcism, which persist alongside with Islam.
\end{abstract}

Keywords: South China Sea, Media Studies, Frenemy, Propaganda, National Interests

\footnotetext{
${ }^{1}$ Eva Rapoport was born in Moscow, USSR. Graduated from the faculty of philosophy, Russian State University for the Humanities. Taught philosophy and cultural studies-related disciplines at the Higher School of Economics and the State Academic University for Humanities, Moscow, Russia. Currently a second-year PhD student of the College of Religious Studies, Mahidol University, Thailand, working on dissertation on Javanese horse dances in the perspective of spirit possession studies. Corresponding email: eva.rapoport@gmail.com.
} 


\section{Introduction}

Jathilan or Javanese horse dance is a unique cultural phenomenon combining dance, music and altered states of consciousness in a form of a spectacular and awesome performance. Unlike widely advertised art forms perceived as manifestations of the higher Javanese culture (such as gamelan orchestra and wayang kulit (shadow puppets) theater), it remains almost unknown to the outside world (for instance, foreign tourists visiting Java would hardly even hear of it), due to its lower, folk and unrefined status, though it is extremely popular among the locals (especially villagers and people with lowincome jobs) and constitutes an essential part of many communal celebrations.

Horse trance dances are widespread all over the island of Java, in different areas they are known by different names, among which the most common are jaranan, jathilan, kuda kepang or kuda lumping ${ }^{2}$. The whole variety of possible terms, depending on the region and sub-genre, is so wide that simply reviewing it could be a subject of a separate detailed inquiry. But even outside Java horse dances can be found almost in any area where Javanese immigrants are present-on other Indonesian islands, in the neighboring countries such as Singapore and Malaysia ${ }^{3}$, even in South American Suriname which has over 13 percent of Javanese population.

Horse dances in the forms quite similar to the ones that can be observed nowadays were already described by the Western ethnographers in the late $19^{\text {th }}$ century (cf. Groenendael, 2008) while the first mentions in Javanese literature date back to the beginning of the $19^{\text {th }}$ century (Ibid., p. 13). How much longer before that it has existeddue to the absence of written sources-is mostly the matter of speculations, but most likely it was already there upon the arrival of Islam to Java ${ }^{4}$ (i.e. $15^{\text {th }}$ century) and it is quite likely that trance practices were part of the ancient Javanese culture even before the adoption of Hinduism (around 6-7th centuries) (Kartomi, 1973, p. 164).

\footnotetext{
2 The whole variety of possible terms, depending on the region and sub-genre, is so wide that simply reviewing it could be a subject of a separate detailed inquiry.

${ }^{3}$ In Malaysian state of Johor horse dances are even positioned as a tourist attraction, with t-shirts and other souvenirs featuring locally used name 'kuda kepang' being sold (remarkably, on Java itself such commodification seems to be non-existent).

${ }^{4}$ Mauricio describes jaranan dor - a certain sub-genre of the horse dance, which was utilized by the Muslim preachers for attracting the audience with the promise of entertainment that was already known and loved (p. 71).
} 


\section{Literature Review}

Javanese horse dances are discussed in various works among which only two go beyond the format of academic paper. These are Victoria M. Clara van Groenendael's monograph Jaranan: the horse dance and trance in East Java, first published in Dutch and translated into English in 2008 and David E. Mauricio's MA thesis Jaranan of East Java: An Ancient Tradition in Modern Times defended at University of Hawaii, Manoa in 2002.

Apart for a few papers dedicated to the horse dance in particular (see Paul Christensen (2013) Modernity and Spirit Possession in Java. Horse dance and its contested magic), mentions of it can be found in sources of a wider and varying scope from Clifford Geertz's classical The Religion of Java (1960) to John Pemberton's contemplation over cultural trends and policies if the New Order-On the subject of "Java" (1994).

\section{Methods}

The scope of the fieldwork for current research was deliberately narrowed to only one area - the Special Region of Yogyakarta (Daerah Istimewa Yogyakarta, or simply DIY) to eliminate any possible regional variations (which, judging by the other researchers' accounts, clearly do exist-cf. Groenendael, Mauricio) and to observe different groups' trance performances that are potentially as similar as possible. The current stage of fieldwork includes thorough documentation of over a dozen performances by different troupes and two in-depth interviews with the members of jathilan collectives conducted during their meetings which are held on more (Kudho Praneso) or less (Kudho Nalendro) regular basis, plus numerous informal communications with Javanese who are involved in the horse dance practices or those to be considered mere spectators.

Jathilan is precisely the name for the horse dance in Yogyakarta area and some neighboring regions. The choice of this particular region for the research has more to do with the characteristics of cultural life in DIY as such rather than any specifics of how horse dances are performed there. For centuries Yogyakarta has been a center of Javanese court culture (and preserved its special status of a sultanate even after the establishment of the Republic of Indonesia) which, apart from the development of performing arts, has raised local mysticism to a rather refined level, furthermore, the cultural policies of the New Order and present-day Indonesia had way wider resonance here compared to most of the other Indonesian provinces. However jathilan in its original 
animistic and ritual form was never fully accepted by the official culture ${ }^{5}$ and always has been an essential part of a village, not of a court life-the more interesting it is to observe its balancing (more than that-flourishing) on the verge of different cultural domains.

\section{Results and Discussion}

In its most authentic form horse dance is performed in villages to celebrate such rites of passage as marriage and circumcision, or as a crucial part of an annual village cleansing ritual (bersih desa). Performance can last for about 5 hours and consists of 4 or 5 parts (babak) with different lead dancers in each. The most typical babak involves an even number of dancers (normally 6 or 8 ) dressed in colorful costumes imitating the ones of noble Javanese warriors ${ }^{6}$. The dancers are 'riding' flat hobby horses made of woven bamboo and could be armed with whips and/or wooden swords. Performance is accompanied with a music of traditional gamelan instruments (mostly various gongs and drums), however an addition of modern drum set is also very common nowadays. The music goes with the voices of one or two singers, performing traditional and popular songs, alongside with some chanting. The dance starts in quite an orderly way with synchronized and elaborate movements. Performing of such routines may last for about 20 or 30 minutes after which begins a trance phase-that presents the main attraction for the spectators.

What distinguishes Javanese horse dances from the majority of known trance practices is the role of a special figure called pawang - which is commonly translated as 'shaman' or quite aptly by Groenendael as 'trance master'. It is only the pawang, not the dancers themselves who is responsible for interaction with spirits, thus for inducing and later ending the state of trance. It is common for the pawing to be a head of the troupe, even an owner of all the props. While jathilan groups are paid money for their performances, it is never sufficient or even expected to be a main source of income and all the participants have their day jobs-usually blue-collar ones, however the pawang

\footnotetext{
${ }^{5}$ Cf. John Pemberton (1994) for a detailed account on how cultural policies of the New Order, while directed toward support of various expressions of traditional culture due to their significance in constituting national identity, were at the same time strictly selective in the attempts to play down all the elements that might have been considered unruly and chaotic (trance among them).

${ }^{6}$ In many variations of jathilan there are also different kinds of masked dancers involved, however, at this point, their typology has to be excluded from this overview not to overcomplicate or overextend it. Only some of the examples are to be mentioned later.
} 
may enjoy a slightly higher social status (thus Groenendael (2008) describes a group ran by the trance master who was a police officer).

According to the perception of all the dancers interviewed, it is exactly the pawang who makes spirits come and possess them, while in the literature it is frequently said that certain tunes, rhythm or movements could be trance inducing (Becker, Bourguignon, 1973, p. 42, Lewis, 2003, p. 34, Herbert, 2011). Though, from all the performances observed it is clear that there are no particular movements or tunes to trigger the trance state for it can occur on different stages of the performance, however seemingly right where and when the pawang meant it, whether the performers start showing obvious signs of trance due to his direct actions (whip cracked or flower petals blown towards the dancers) or merely in the process of the dance (rather typical moment-during a mock fight that gradually turns into something more real) or in a pause when the orchestra stops for a while before starting to play a new tune.

The occurrence of trance flips the performance from order into chaos. The dancers can start yelling and rolling on the ground, somersaulting in seemingly impossible for a person in a normal waking consciousness ways, some can sit still with a blank stare on the face while others aimlessly wander around with their eyes rolled so no pupils are visible. The most remarkable part, though not necessarily included into every performance, is demonstration of various feats. Entranced dancers can husk big green coconuts with their teeth and hands, eat broken glass or razors, lick fire, walk on hot coals, be whipped or even lie down and be run over by a motorcycle-all without any visible harm to their bodies.

Everything is believed to become possible due to the involvement of spirits possessing the dancers' bodies during the performance. Trancing might last for about an hour and needs to be ended by the acts of exorcism, performed by the pawang and some of his helpers. Usually the dancers are taken out one by one and the attempts to restore them back to their normal consciousness can be also very dramatic and not always instantly successful. The techniques employed by the pawangs allow certain vitiations but the most common can be described as 'hold and release' when the pawang is holding something invisible on the dancer's back or back of the head and after clenching his fists really tight eventually releases the grip and gestures as if removing somethingsomething, which, if no longer attached, can simply float away. Other methods can involve 
rubbing dancer's ears or blowing into them ${ }^{7}$, covering the body with a piece of cloth, almost using it like a shroud, and various tricks with whips and hobby horses. Even within a single performance it is not unusual to see quite different exorcist techniques performed over different dancers.

Interesting is overall symbolism of a horse which is perceived as a creature yielding its will to the rider same as the dancers should submit themselves to the spirits (Mauricio, 2002, p. 23). Effigies are basically believed to be possessed themselves, so, according to some accounts (Ibid.) anyone who holds a properly 'charged' horse is expected to become possessed due to that. There are special rituals performed for the horses when they are supposed to be cleansed and the link with the spirits is established anew. Hobby horses, being way more than mere props, are made by special masters and there is no fixed time for how long it might take because the starting point is just finding a right bamboo ${ }^{8}$; only five colors (white, red, yellow, black and light blue-each with its own symbolism) are used to paint the effigies. But what makes the horses more remarkable is the fact that at least as a metaphor of one's will being submitted they play quite similar role in possession cults of entirely different cultures. In various South American and Caribbean cults of African descent mediums themselves are called spirits' or deities' horses and that is how the spirits, if speaking through the possessed individuals, refer to the latter (cf. Bourguignon, 1989, 2005, Lewis, 2003, p. 51). Moreover, spiritual mediums in Southern Thailand that get possessed by Chinese deities and are also famous for performing feats based on physical invulnerability are called ma song which literally means 'a horse to be ridden' (personal communication).

So to consider jathilan in a comparative perspective and employ the framework suggested by the lead theorists in an interdisciplinary field of trance and spirit possession studies, jathilan can be classified as an adorcist practice (cf. de Heusch) where contact with spirits is deliberately sought in particular ritualized context (in opposition to exorcist angle when possession is only perceived as something undesired), thus possession by the spirits-when they arrive and when they leave-is cautiously controlled, as it is voluntarily and willingly induced, and it is clearly an example of

\footnotetext{
${ }^{7}$ Same tricks for stopping trance are frequently used in Thai ceremony Sak Yant Wai Kru where the participants are believed to become possessed by their sacred tattoos.

${ }^{8}$ Bamboo thickets themselves are commonly believed to be populated with spirits (Geertz, 1960, p. 19). 
possession trance (PT in classification suggested by Erika Bourguignon (1973, p. 12) ${ }^{9}$ ), since both-verifiable altered states of consciousness and belief in spirits-are involved.

While it is obvious that the dancers themselves do not have any shamanistic properties (i.e. initiate the contact with the spirits at will), it is harder to define pawang's or trance master's status. It is not uncommon for the pawangs to be former dancers themselves, which implies they have their own history of experiencing trance, however for conducting a performance, trance is absolutely not required, though pawang or his helpers may become possessed during the most intense acts of exorcism. Pawang maintains his relationship with the spirits through special rituals some of which are kept in secret, but there are no accounts of pawang's own soul travelling elsewhere, especially considering that in Javanese beliefs spiritual, unseen world (alam gaib) is not a separate place, it is more like spirits are thought to live side-by-side with the humans, while quite real geographic locations-like mountains or an ocean shore-are considered to have the densest spirits population. According to Pak Samsul, pawang and a head of Kudho Nalendro group (Sleman, Yogyakata Special Region), pawangs have particular friendly spirits whom they are constantly in contact with and who are exclusively meant to possess the dancers during the performance. However, in some areas where a lot of spirits are present, strange spirits can attempt to possess the performers instead of familiar ones, so this possession could be less controlled and more dangerous.

There is particular paraphernalia involved in interaction with spirits. Most of the performances are preceded with a short sequence of ritual actions meant to invite the spirits. However each pawang does these somehow differently (and in the least ritualized contexts nowadays such preparations could be skipped completely) two main elements are mostly the same: these are incense (joss) sticks burned and crimson and white flower (rose) petals strewn. Although many modern Javanese who are not personally involved in any possession practices associate these joss sticks with Chinese religion, rose petals and incense are precisely believed to be spirit's food ${ }^{10}$. There are also certain aroma potions (small industrially produced vials) which are supposed to be liked by the spirits, so many pawangs give them to the entranced dancers to drink or to sniff. Despite the

\footnotetext{
${ }^{9}$ Bourguignon also distinguishes trance as such (T) which does not presuppose any spirits to be involved, and non-trance possession which is associated with spirits but does not involve any striking behavioral changes (1973).

${ }^{10}$ In the city of Yogyakarta in quite a close proximity to its center there is even a small shop (warung roh halus) selling specialized food for the spirits.
} 
spirits' alleged preferences, due to the strong scent, such potions seem to be working quite well in bringing about the performers who are so deep in trance that they cannot even stand. Some more conventional food could be also present-as an offering to the spirits: a big cone of rice with a whole fried chicken and occasional eggs and vegetables would be put in the corner of the performance area (it might get eaten by the entranced dancers, but quite frequently stays untouched till the very end); or various kinds of food prepared for the dancers precisely: ranging from something quite casual (like watermelon slices) to something more suitable for the actual horses (like unhusked grain), which the possessed dancers nevertheless would be able to eat.

Apart from commanding the spirits, pawangs are commonly believed to have some other powers-which can significantly vary in case of each particular pawang. In general, those may include healing (which would be provided only for the group and family members) and finding lost items. There are also other kinds of pawangs, unrelated to jathilan, like those who can summon rain. As Pak Samsul readily reported about himself, before starting jathilan group - which he decided to do out of fondness of this art formhe used to practice all kinds of magic, including the black one, while his abilities were the result of continuous learning from different other practitioners whose guidance he sought since adolescence. On the contrary, Pak Ambang, the pawang of Kudho Praneso group (Sleman, Yogyakata Special Region), who seems to have spiritual but less of administrative power in his collective, described himself as an autodidact-so he was just born with the special powers and gradually learned how to use them and what to apply them to. Both pawangs said that virtually everyone can learn to be a pawang-thus to gain the ability to command the spirits during the performance and make them leave in the end, but those people who do not have a natural gift can only be weak pawangs. Burridge also reports that "capacity for being a pawang is considered to be inborn. It's a gift which may be developed but not learned" (1961, p. 34).

By observing performances of different groups, it is easy to notice that different pawangs demonstrate quite different powers: while some only release their dancers from trance through a thoroughly executed exorcism procedure others can make dancers fall unconscious by merely touching their heads or influence them from the distance in order to make them come closer or even somersault-by merely blowing flower petals in their direction. In Pak Samsul's own group most of the control over the performance was handled by his three younger disciples, whom he wouldn't even call the pawangs yet, but 
whom he was preparing to replace himself based on the idea that, since most of the audience is quite young, so should be the pawangs.

Interestingly, the ideas on who can become possessed were not the same in the two groups: while Pak Samsul said that he can make anyone possessed and not necessarily within the performance but also on instant (which he demonstrated on two of his dancers during the 'bathing' ceremony for the group's house effigies); in Kudho Praneso there is a dancer, who is also a son of the same group's dancer-so has been exposed to jathilan practices from the earliest age (which is not uncommon) but had never ever become possessed in his life, which, nevertheless, was not an obstacle for him being a member of this group.

It is actually normal, that not all of the dancers become possessed during the performance and those who don't just leave and don't participate in the trance part; but who exactly does and who doesn't get to be possessed is commonly expected to be accidental for every single performance. Interesting in this case is Pak Samsul's take on the issue: while he claims that it is only for him to decide who becomes possessed, he also said that maintaining and bringing back to normal all the eight dancers of every babak would be too tiring for the pawang and his helpers, so only some actually get possessed and demonstrate the most remarkable trance behavior, while the others just have to pretend to be slightly in trance. However, it is never discussed with the dancers, so, starting the performance, they don't have any idea whether they are going to become possessed or not.

There are significant variations in what the dancers can or cannot do while in trance, depending on the group they belong to. Most of the entranced dancers appear to be completely unable to talk or having a big difficulties with it, so they have to communicate their needs merely with gestures (they might ask the orchestra to play another tune, or the same but faster, ask their pawang for a potion or incense sticks, which they might chew, hold in the mouth from the end that is not burning or actually lick the burning end, they might ask a helper to whip them, which is never done without the dancer's preliminary consent, etc.). But in some groups the dancers do talk (with changed, unnatural voices) and even communicate with the audience, though demonstrate a remarkable inability to stay focused on a particular dialog for more than one or two minutes; there are even groups where deeply entranced dancers still perform some elaborate dance routine-despite the common sequence in which all the orderly 
dancing is performed only in prior to the trance phase. Feats as well might differ-from no other specific actions rather than entranced behavior itself to the most extreme (and more rare ones) like chewing and swallowing glass (usually shattered lightbulbs) ${ }^{11}$, seemingly the most common and relatively harmless display of the possessed performers' abilities is husking green coconuts with bare teeth and hands.

However, all the variations in question were performed by the groups from the same region and notwithstanding the fact that, in general, groups, as many admit, tend to borrow and learn from each other (at least, with regard to music, costumes and dance routines), every group's performance has something distinguishing it from all the others, in terms of pawang's and entranced dancers' abilities, the ways trance is induced and ended. Trance appears to be not a strictly ritualized practice but a space for personal creativity (at least in case of pawang's modus operandi) and intuitive learning. Possibly, trance is always performed differently because it is a priori such a spontaneous activity that defies any thoroughly established ways of reproduction, or at least these ways cannot be equally suitable for all the performers and trance masters.

Javanese possession (quite in line with the description of the principles of possession as such suggested by Cohen \& Barret) is perceived as a complete replacement of the trancer's agency, and what is common for a naturally induced possession trance (i.e. without use of any psychedelic substances) performers have no recollections of what they were doing. In terms of beliefs (which also is not unusual) there is no clear explanation of what happens to the person's soul, even the particular nature of the spirits is also unclear for almost everyone, including the dancers. Only the pawang can identify the spirits, thus know what their needs could be and which exorcism techniques would be the most efficient ones. And while the pawang may have an established relationship with a few particular spirits, for the regular horse dancers there is no connection between particular performers and particular spirits usually possessing them (unlike some African and Afro-American cults where mediums can have an established link with one or several particular spirits or deities-going as deep as these relations might be

\footnotetext{
11 Performers doing so can be observed from rather close distance and there seems to be no signs of blood whatsoever in these people's mouths. Out of 12 performances, all by different groups, documented in JuneJuly 2017 there was only one group that demonstrated this feat. Remarkably, in case of another group's performance, when the dancer occasionally broke a glass he was drinking from, pawang's assistants made sure it was immediately taken away so no one got hurt.
} 
described (and even registered in an 'official' document) as marriage (Lewis, 2003, pp. 52-55)).

Although in some accounts it is said that trance in jathilan is performed only by men for there are certain dangers possession presents for young women and can have a negative impact on their future children (Mauricio, 2002, pp. 44-45), many groups in Yogyakarta actually have female dancers who perform trance as well, though the manner in which they do it is generally quite different. All-female trance part (as in each babak the dance with the horse effigies is performed only by the dancers of the same gender and more or less the same age) might include nothing else but continued dancing in some somnambulist state-the changes in facial expressions and the lack of the eye movements might be the only indicators of a transformation of the dancers' mental state. But, while some female trances are like that, others could be still very intense-with rolling on the ground, yelling and not being responsive to the very first attempts of exorcism.

Interesting is the difference in the ideas of the two interviewed groups on the matter of female participation. Kudho Praneso has no female dancers and-whether it is an exhaustive and true explanation or not-in response to the question 'why' the group members readily explained, with some awkward laughs, that for a male pawang and his helpers it could be a tricky task to take care of women and perform exorcism on them since it is unclear how to hold them, to restrain their movements, if necessary, and not to do it in any inappropriate way. In contrast, Pak Samsul from Kudho Nalendro not merely has young women in his group but says, he prefers them, not men to do the feats-e.g. eating razors. According to him, all is for the pawang to decide: who is going to be possessed and who is going to perform feats as well, so he simply finds women doing these more spectacular. One of the female performers of Kudho Nalendro is Pak Samsul's own daughter, whom he also doesn't mind eating razor, so they both speak of it with quite an enthusiasm. Some of the dancers say that men and women are possessed by different spirits, therefore their trances look differently, although occasionally women can be as fierce as men-all depending on the particular spirit.

While the pawangs are predominantly male, in Yogyakarta area there are at least two female pawangs who seem to be working in pair but joining different groups' performances and could be even listed on a poster announcing the performance ${ }^{12}$ as a

${ }^{12}$ Seemingly all the jathilan performances in Yogyakarta region are advertised online through various social media with such posts created by the members of the performing groups themselves; and there is at 
special attraction. However, in the performances observed these two female pawangs were never seen performing exorcism without a help of at least one more male trance master. So, despite some confusion regarding the appropriateness of female trancing, at the very least, possession in jathilan (and in Javanese culture in general) cannot be called exclusively masculine or feminine practice.

Apart from the 'horse riders' which are the most emblematic for the general idea of the dance, various parts of jathilan performances can also introduce other characters with more clear trancing specialization: such as barong-a wooden animal head-like mask with a moveable lower jaw, representing forest spirit or king of all forest spirits, or celeng - a wild boar, similar to horse effigy, but usually made of rubber or leather, and some others. Celeng, portrayed by a shirtless man with a blackened face and, quite often, a large belly, has probably the most distinctively recurring trance behavior. If there is one (sometimes two) celeng involved in the babak there would be a mud pond dug in the corner of the performance area; while in trance-to the great amusement of the spectators-celeng is going to dive in the mud and try to throw muddy water on anyone who is incautious enough to stay dangerously close.

Not only the dancers, but also musicians or even spectators can become possessed during the performance. Though in case of the bystanders it is commonly understood that those who have their own experience of trance possession are most likely to be influenced by the music and vibe of the performance. An alternative explanation implies that spectators become possessed only when the spirits are dissatisfied so they disrupt the normal course of performance to express their displeasure (Christensen, 2013, p. 10).

Thus, alongside with all the controlled possession instances, spontaneous type is also quite common. The members of Kudho Praneso group were readily telling that it is quite usual for them to become possessed in everyday life, especially if they are 'having some problems'. So, the mental state is an important factor for possession whether it occurs during the performance (according to Pak Samsul, those who are currently troubled become possessed way easier) or outside of it. As for Kudho Praneso dancers, they (or most likely their family members) always seek help of their pawang on such occasions, which does not present any difficulties since they are all neighbors. However, Pak Ambang claims that he can even perform exorcism over a telephone if necessary.

least one active Facebook group accumulating information about all the upcoming performances on a monthly basis. 
Numerous examples of ordinary people becoming spontaneously possessed are described by Clifford Geertz throughout The Religion of Java (1960) and there are clearly instances of the two types of possession: executive and pathogenic (dichotomy suggested by Emma Cohen); while former more or less coincides with Bourguignon's definition of possession trance, the latter does not involve any explicit altered states of consciousness, but can be 'diagnosed' in case of changes in person's behavior that can be noticed only in the long run or some illness (especially the one seemingly unidentifiable and incurable by the biomedicine) as these occurrences can be also believed to be caused by the spirits.

Most of the present-day Javanese informants who had no relation to any performing groups, were ready to come up with some stories of their acquaintances or family members becoming suddenly possessed for some identified (e.g. passing by a cemetery) or unidentified reasons. In cases of spontaneous possession 'empty thoughts' (Ferzacca, 2002, p. 99) or 'empty soul' are believed to be a factor attracting the spirits. "If one is upset, startled, or severely depressed, one becomes confused and disoriented, and one's soul is then empty and easily entered by the spirits" (Geertz, 1960, p. 97). As another cause of an empty soul is believed to be the lack of 'spiritual discipline' which supposed to be maintained through meditation and fasting (Ibid. p. 98).

Considering that jathilan trance masters do not tend to apply their powers outside their group and family, there are other types of ritual specialists to perform exorcism in cases of possession that occurs in everyday life and diagnose latent pathogenic possession in the first place. These are dukuns (or dhukuns)—practitioners of traditional medicine and spiritual healing, holding the knowledge regarding traditional rites but also of magic and sorcery.

Although Geertz (pp. 86-87) is describing dukuns as ritual specialists with a wide range of specializations (from midwives and wedding specialists to massage and acupuncture masters), for many younger Javanese informants all these socially important (at least in the past) roles are overshadowed by the image of a dangerous occult figure, someone practicing sorcery (at best - associated with love magic and questionable ways of becoming rich). Most of the informants even hypothetically would not admit that they might need the help of dukun in whatever case, some (evidently with closer ties to Islam) would even say that dukuns are 'officially' haram. All rather claim that in case of possession their families would seek the help of a kyai-religious specialist affiliated with Islam. But overall suspicion toward dukuns is not a complete novelty as there have always 
been certain ambivalence in how they can be perceived. However skilled in various kinds of traditional healing (which was especially relevant prior to the spread of the Western biomedicine), dukuns were always suspected of being equally capable of inflicting harm (cf. Geertz, Foley).

While in the context of the horse dance, terms 'pawang' and 'dukun' can be sometimes used interchangeably (and quite common East Javanese name for a trance master is gambuh), there are also special types of dukuns who become possessed themselves-these include dukun tiban and dukun prewangan. The first is described by Geertz as 'possessed curer' (p. 100); tibans suddenly gain their ability to heal (the name can be roughly translated as "fallen as a wonder from the skies" (Ibid.)) and it rarely lasts longer than a few years but even a few months could be enough for them to become a local sensation and start seeing dozens of patients every day. Judging by Geertz's description tiban's possession is more of a latent one, without explicit displays of trance.

Dukun prewangan acts pretty much like a spiritual medium in the Western culture. Prewangan can become possessed by the spirits of the dead at will and let them speak to the clients who are seeking contact with the diseased loved ones; prewangans tend to have no recollections of anything that was said during the séance. While the majority of dukuns (with the exception of those who specialize in midwifery) are predominantly male, tibans and prewangans are generally female; the latter, despite their ability to communicate with the unseen world, seem to enjoy significantly less respect than the trance masters of the horse dance (Groenendael, 2008, p. 27), tibans are believed to use 'darker powers' which makes their practice not so socially acceptable (Geertz, 1960, p. 100). Furthermore, both mediums and possessed healers are described by Geertz as more psychologically unstable and disturbed, while most of the other dukuns appear to be perfectly normal members of their societies (pp. 100-103).

All this sophisticated taxonomy indicates that Javanese culture has a highly developed system of spirits and possession beliefs and various kinds of possession (including spontaneous, involuntarily, and latent), as well as the specialists in possession (tibans and prewangans) and exorcism (dukuns, kyayi), apart from those to be observed in case of the horse dance. Among the performing arts, jathilan is also, by far, not the only genre based on displays of trance, the others-just to make a list-are: reyog ${ }^{13}$, dabus,

\footnotetext{
${ }^{13}$ Reyog and jathilan are definitely related, for the former performance involves particular type of dancers (which in the past used to be young good-looking boys but later were replaced with young women) riding
} 
sintern, angguk, dolalak and nini thowok. The latter presents a certain peculiarity since in this case the spirits are expected to possess not a human performer but a human-sized doll, which is believed to become animated as they arrive. Even in specifically Islamic art forms (like rodat, montro, badui ${ }^{14}$ ) certain elements of trance are involved, these are also some kinds of dances which are performed in a sitting position, and express devotion to God instead of interaction with spirits.

Jathilan itself shows a remarkable potential to creating a peculiar symbiosis with the world religions professed in Indonesia. Many modern pawangs (but definitely not all of them, as neither Pak Samsul nor Pak Ambang made any direct references to their belief in God) explain their abilities not as indication of their own power but only as something granted by Allah for their devotion ${ }^{15}$, while Arabic prayers could be used even by the less islamized pawangs alongside with Javanese mantras. More than that, Christianity that is also widespread on Java, can as well be combined with possession beliefs and practices, for there are said to exist Christian pawangs (Hughes-Freeland, 2008, p. 40), while at least in Yogyakarta area invitations of jathilan groups to perform on various Church communities' events (including celebration of Christmas and Easter) are actually quite common.

Overall richness of Javanese spirit and magic lore surrounding the practice of jathilan and its own exceptional adaptability attests to general persistence of the indigenous Javanese religion which under a broad label of 'beliefs'-aliran kepercayaan (embracing all the indigenous religions of Indonesia) has finally gained official recognition by the government in 2017.

\footnotetext{
identical flat hobby horses and named jathil. But the exact connection between the two genres, even if pointed out, is not explained in any literature, nor any of jathilan performers in Yogyakarta have a clear understanding of it. More common are the claims that jathilan originates from reyog (rather than any other way around), but for how, when and why is never given any satisfactory clarification.

${ }^{14}$ Only the last one is still practiced while the other two are said to become extinct after the Independence (personal communication with Kuswarsantyo, professor of the dance department it the Yogyakarta State University).

${ }^{15}$ It doesn't mean that there is no severe criticism of possession rites from more strict Muslims, but, at least for those who practice or fondly watch possession performances, beliefs in Javanese spirits and Allah can pretty much come along.
} 


\section{Conclusion}

Javanese horse dances exist and persist in the context highly saturated with beliefs in spirits and spirit possession. A type of possession involved in the dance (voluntarily achieved for a limited time in the controlled environment under the supervision of a trance master) is only one of many kinds that occur in Java, while horse dances themselves are, by far, not the only performing genre involving trance. But their flexibility, adaptability and attractiveness for the spectators and community-building role in case of the performing groups members, allows the horse dances their place among the most popular and wide-spread of all Javanese arts.

\section{References}

Becker, J. (1994). Music and Trance. Leonardo Music Journal, 4, 41-51.

Bourguignon, E. (2005). Spirit Possession. In Casey, C. \& Edgerton, R.B. (Eds.) A Companion to Psychological Anthropology: Modernity and Psychocultural Change (pp. 374-388). Blackwell Publishing Ltd.

. (1989). Multiple Personality, Possession Trance, and the Psychic Unity of Mankind. Ethos, Vol. 17, No. 3, 371-384. (1973). Introduction: A Framework for the Comparative Study of Altered States of Consciousness. In Bourguignon, E. (Ed.) Religion, Altered States of Consciousness and Social Change (pp. 3-39). Columbus: Ohio State University Press.

Burridge, K. (1961). Kuda Kepang in Batu Pahat, Johore. Man, 61, 33-36.

Cohen, E. (2008). What is Spirit Possession? Defining, Comparing, and Explaining Two Possession Forms. Ethos, 73(1), 101-126.

Christensen, P. (2013). Modernity and Spirit Possession in Java. Horse dance and its contested magic. Dorisea Working Paper, 2, 2-13.

De Heusch L. (1971). Why Marry Her? Society and Symbolic Structures. Cambridge: Cambridge Univ. Press.

Ferzacca, S. (2002). A Javanese Metropolis and Mental Life. Ethos, 30 (1/2), 95-112.

Foley, K. (1984). Of Dalang and Dukun-Spirits and Men: Curing and Performance in the Wayang of West Java. Asian Theatre Journal, 1(1), 52-75.

Geertz, C. (1960). The Religion of Java. Chicago: The University of Chicago Press.

Groenendael van, V. M. C. (2008). Jaranan: the horse dance and trance in East Java. Leiden: KITLV Press. 
Herbert, R. (2011). Reconsidering Music and Trance: Cross-cultural Differences and Cross-disciplinary Perspectives. Ethnomusicology Forum. Vol. 20, No. 2, 201-227.

Hughes-Freeland, F. (2008). "Becoming a Puppet”: Javanese Dance as Spiritual Art. The Journal of Religion and Theatre, Vol. 7, No. 1, Fall.

Kartomi, M. J. (1973). Music and Trance in Central Java. Ethnomusicology, Vol. 17, No. 2, May.

Lewis, I. M. (2003). Ecstatic Religion: A Study of Shamanism and Spirit Possession (Third Edition). New York, NY: Routledge.

Mauricio, D. E. (2002). Jaranan of East Java: An Ancient Tradition in Modern Times. University of Hawaii at Manoa.

Pemberton J. (1994). On the subject of "Java". New York: Cornell University Press. 